\title{
Computare Vision Berbasis Camera dan Mini PC untuk Identifikasi Kecacatan Penutup Kemasan Minuman Kaleng
}

\section{Computare Vision-Based Mini PC and Camera In Identifying Defective Packaging Closures of Beverage Cans}

\author{
Andrizal $^{1)}$, Anton Hidayat ${ }^{1)}$, Roza Susanti $^{(1)}$ \& Rivanol Chadry ${ }^{2)}$ \\ ${ }^{1)}$ Jurusan Teknik Elektro Politeknik Negeri Padang Kampus Limau Manis Padang 25163 \\ Telp 0751-72590 Fax 0752-72576 Email: andrizalpoli@ gmail.com, antonramiati@ gmail.com \\ 2) Jurusan Teknik Mesin Politeknik Negeri Padang Kampus Limau Manis Padang 25163 \\ Telp 0751-72590 Fax 0752-72576 Email: rivanolchadry@ yahoo.com
}

\begin{abstract}
visual inspection becomes an important role when determining the quality of the conditions of production. Manual visual inspection carried out by relying on human senses, especially the eyes, the weakness is perspective and human's perspective may be different from each other, the quality result can be different. Utilization of the camera as a sensor and computer system as a major component of decision-making is the latest technology that is used as an automatic visual inspection replace human tasks. This research aims to make a visual inspection system that utilizes a web camera and mini PC (personal mini computare) Raspberry PI to identify disability packaging beverage cans. The system that is made has been tested to identify defects tin side of the inner surface of the cover packaging of canned drinks without color or silver color. The result is, the system is able to distinguish defective cans and the cans that are not defective with an accuracy of 66, 67\%. We hope this research can be developed at a later stage so that automatic a visual inspection can be realized.
\end{abstract}

Keywords: Visual inspection,defective, cans

\section{PENDAHULUAN}

Penanganan pasca produksi memegang peranan penting dalam penentuan mutu hasil produk, terutama kegiatan sortasi dan pemutuan apakah produk yang dihasilkan cacat atau tidak cacat. Kegiatan sortasi dan pemutuan dapat dilakukan secara manual seperti dengan memanfaatkan panca indra manusia. Ketika pemutuan dan sortasi dilakukan secara manual, memunculkan permasalahan yaitu kurang efektif dalam mengamati kecacatan terutama kecacatan kemasan seperti kemasan minuman kaleng. Kecacatan pada kemasan tersebut terkadang tidak dengan langsung bisa diperhatikan oleh mata manusia. Karena pandangan mata seseorang sangat relatif sehingga tidak sama dalam menilai bentuk suatu barang. Akibatnya, jika hanya menggunakan pandangan mata, maka sulit untuk memastikan akurasi keputusan bahwa suatu kemasan dinyatakan cacat atau tidak cacat.
Penggunaan panca indra vision manusia pada sistem pemutuan manual dapat digantikan dengan menggunakan kamera digital. Hal ini dilakukan dengan mengolah hasil capture gambar yang didapat melalui kamera digital. Kemampuan kamera dalam menangkap sebuah objek bisa menyerupai fungsi mata, dimana hasil yang sudah dicapture disimpan sebagai sebuah image atau citra dari objek tersebut. Citra atau image ini merupakan representasi, imitasi, atau kemiripan dari suatu objek yang memiliki informasi yang secara umum tersimpan dalam pemetaan bit-bit atau sering dikenal dengan bitmap. Hasil pengolan citra dalam bentuk konversi nilai RGB (Red, Green, Blue) dikonversi menjadi nilai biner. Nilai biner image merepresentasikan kondisi permukaan suatu objek. Jika permukaan objek rata, atau mulus, maka nilai biner akan terang atau 0 . sementara ketika permukaan objek tidak rata, nilai biner akan gelap atau 1 (255). 


\section{Citra Digital}

Citra digital merupakan representasi image dengan fungsi intensitas cahaya $f(x, y)$ dimana nilai $\mathrm{x}$ dan y merupakan koordinat spasial dan nilai fungsi tersebut pada setiap titik $(x, y)$ merupakan tingkat kecemerlangan atau intensitas cahaya citra pada titik tersebut. Citra digital adalah citra $f(x, y)$ dimana dilakukan diskritisasi koordinat spasial (sampling) dan diskritisasi tingkat kecemerlangan / keabuan (kwantisasi)

\section{Elemen-Elemen Citra Digital}

Citra digital mengandung sejumlah elemenelemen dasar. Elemen-elemen dasar tersebut dimanipulasi dalam pengolahan citra dan dieksploitasi lebih lanjut dalam computer vision. Elemen-elemen dasar yang penting diantaranya adalah:

1. Kecerahan (brightness)

Kecerahan adalah kata lain untuk intensitas cahaya. Sebagaimana telah dijelaskan pada bagian penerokan, kecerahan pada sebuah titik (pixel) di dalam citra bukanlah intensitas yang riil, tetapi sebenarnya adalah intensitas ratarata darisuatu area yang melingkupinya. Sistem visual manusia mampu menyesuaikandirinya dengan tingkat kecerahan (brightness level) mulai dari yang paling rendah sampai yang paling tinggi dengan jangkauan sebesar $10^{10}$.

2. Kontras (contrast)

Kontras menyatakan sebaran terang (lightness) dan gelap (darkness) di dalam sebuah gambar. Citra dengan kontras rendah dicirikan oleh sebagian besar komposisi citranya adalah terang atau sebagian besar gelap. Pada citra dengan kontras yang baik, komposisi gelap dan terang tersebar secara merata.

3. Kontur (countur)

Kontur adalah keadaan yang ditimbulkan oleh perubahan intensitas pada pixelpixelyang bertetangga. Karena adanya perubahan intensitas inilah mata kita mampu mendeteksi tepi-tepi (edge) objek di dalam citra.
4. Warna (color)

Warna adalah persepsi yang dirasakan oleh sistem visual manusia terhadap panjang gelombang cahaya yang dipantulkan oleh objek. Setiap warna mempunyai panjang gelombang $(\lambda)$ yang berbeda. Warna merah mempunyai panjang gelombang paling tinggi, sedangkan warna ungu (violet) mempunyai panjang gelombang paling rendah. Warna-warna yang diterima oleh mata (sistem visual manusia) merupakan hasil kombinasi cahaya dengan panjang gelombang berbeda. Penelitian memperlihatkan bahwa kombinasi warna yang memberikan rentang warna yang paling lebar adalah red $(R)$, green $(G)$, dan blue $(B)$.

5. Bentuk (shape)

Shape adalah properti intrinsik dari objek tiga dimensi, dengan pengertian bahwa shape merupakan properti intrinsik utama untuk sistem visual manusia. Manusia lebih sering mengasosiasikan objek dengan bentuknya ketimbang elemen lainnya (warna misalnya). Pada umumnya, citra yang dibentuk oleh mata merupakan citra dwimatra (2 dimensi), sedangkan objek yang dilihat umumnya berbentuk trimatra (3 dimensi). Informasi bentuk objek dapat diekstraksi dari citra pada permulaaan pra-pengolahan dan segmentasi citra. Salah satu tantangan utama pada computer vision adalah merepresentasikan bentuk, atau aspekaspek penting dari bentuk.

6. Tekstur (texture)

Tekstur dicirikan sebagai distribusi spasial dari derajat keabuan di dalam sekumpulan pixel-pixel yang bertetangga. Jadi, tekstur tidak dapat didefinisikan untuk sebuah pixel. Sistem vissual manusia pada hakikatnya tidak menerima informasi citra secara independen pada setiap pixel, melainkan suatu citra dianggap sebagai suatu kesatuan. Resolusi citra yang diamati ditentukan oleh skala pada mana tekstur tersebut dipersepsi. Sebagai contoh, jika 
kita mengamati citra lantai berubin dari jarak jauh, maka kita mengamati bahwa tekstur terbentuk oleh penempatan ubinubin secara keseluruhan, bukan dari persepsi pola di dalam ubin itu sendiri. Tetapi, jika kita mengamati citra yang sama dari jarak yang dekat, maka hanya beberapa ubin yang tampak dalam bidanng pengamatan, sehingga kita mempersepsi bahwa tekstur terbentuk oleh penempatan pola-pola rinci yang menyusun tiap ubin.

\section{Citra Biner}

Citra biner biasa disebut dengan citra monokrom. Citra ini terdiri dari 2 warna saja yaitu hitam dan putih. Sedangkan representasi dari citra biner adalah angka 1 untuk warna hitam dan angka 0 untuk warna putih seperti gambar berikut :

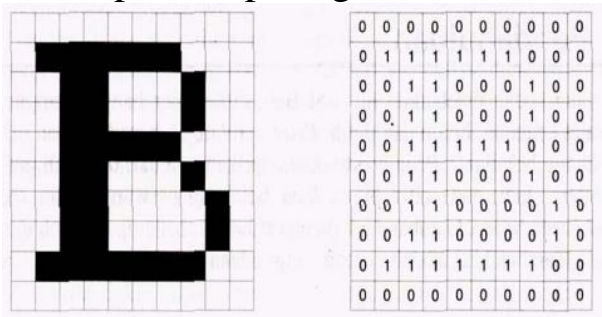

Gambar 1. Citra Biner

\section{Citra Warna}

Warna-warna yang diterima oleh mata manusia merupakan hasil kombinasi cahaya dengan panjang gelombang berbeda. Penelitian memperlihatkan bahwa kombinasi warna yang memberikan rentang warna yang paling lebar adalah red $(R)$, green $(G)$, dan blue $(B)$. Ketiga warna tersebut dinamakan warna pokok (primaries), dan sering disingkat sebagai warna dasar $R G B$.

Setiap pixel dari citra warna, sebagai contoh citra warna 24 bit diwakili dengan 24 bit sehingga total 16777216 variasi warna. Setiap poin informasi pixel (RGB) disimpan kedalm 1 byte data. 8 bit pertama menyimpan nilai biru kemudian di ikuti dengan nilai hijau pada 8 bit kedua dan pada 8 bit terakhir merupakan warna merah. Setiap titik (pixel) pada citra warna mewakili warna yang merupakan kombinasi dari tiga warna dasar yaitu merah hijau biru citra RGB (Red Green Blue). Setiap warna dasar mempunyai intensitas sendiri dengan nilai maksimum 255 (8 bit).

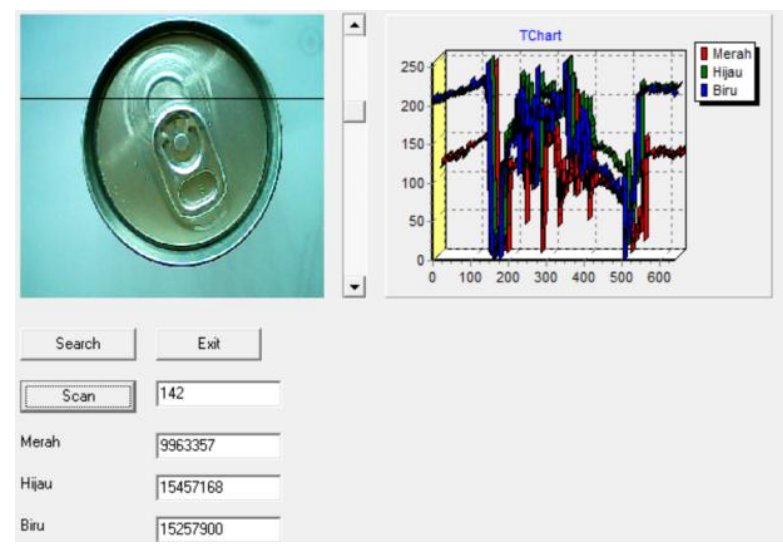

Gambar 2. Citra warna dan komponen warnanya

\section{Histogram Citra}

Histogram citra adalah grafik yang menggambarkan penyebaran nilai-nilai intensitas pixel dari suatu citra atau bagian tertentu di dalam citra. Dari sebuah histogram dapat diketahui frekuensi kemunculan nisbi (relative) dari intensitas pada citra tersebut. Histogram juga dapat menunjukan banyak hal tentang kecerahan (brightness) dan kontras (contrast) dari sebuah gambar. Karena itu, histogram adalah alat bantu yang berharga dalam pekerjaan pebgolahan citra baik secara kualitatif maupun kuantitatif.

Histogram citra banyak memberikan informasi penting sebagai berikut: $:^{[21]}$

a. Nilai $h i$ menyatakan pluang (probability) pixel, $\mathrm{P}(i)$, dengan derajat keabuaan $i$. Jumlah seluruh nilai hi sama dengan dengan 1 , atau

$$
\sum_{i=0}^{L-1} h i
$$

Peluang suatu pixel memiliki derajat keabuan lebih kecil atau sama dengan derajat keabuan tertentu adalah jumlah hi, untuk $0 \leq \mathrm{i} \leq \mathrm{j}$, atau

$$
\sum_{i=0}^{j} \quad h i=P(i \leq j) \quad 0 \leq \mathrm{j} \leq 1
$$

b. Puncak histogram menunjukan intensitas pixel yang menonjol. Lebar dari puncak menunjukan rentang 
kontras dari suatu gambar. Citra yamg mempunyai kontras yang terlalu terang (overexposed) atau terlalu gelap (underexposed) memiliki histogram yang sempit. Histogramnya terlihat hanya menggunakan setengah dari daerah derajat keabuaan. Citra yang baik memiliki histogram yang mengisi daerah derajat keabuaan secara penuh.

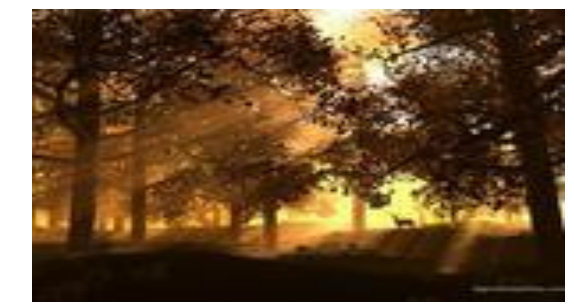

a. Citra pemandangan

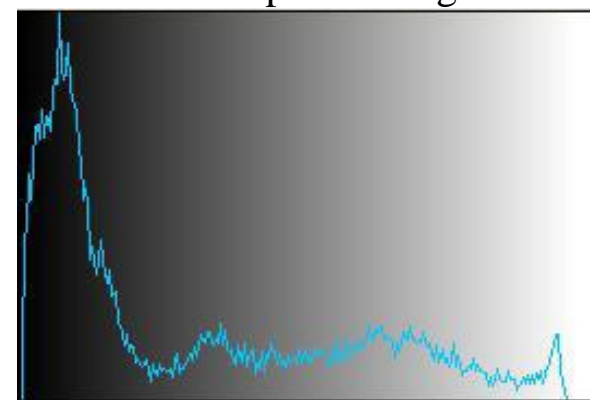

b. Histogram

Gambar 3. Citra Dengan Hitogramnya

\section{Capture Image}

Merupakan proses pengambilan gambar atau image dengan menggunakan alat bantu tertentu seperti web camera.

Web camera merupakan sebuah sistem kamera yang biasanya digunakan untuk mengambil gambar objek sacara terus menerus atau dalam interval waktu tertentu. Hasil capture kamera jenis ini dapat disimpan dalam bentuk frame tunggal yang dapat digunakan untuk proses tertentu. Hasil capture web camera umumnya dalam bentuk citra warna dengan format tertentu.

Pengolahan citra bertujuan untuk memperbaiki kualitas citra atau melakukan perubahan-perubahan terhadap komponenkomponen citra.

Beberapa penelitian yang telah dilakukan sebelumnya terkait dengan proses identifikasi berbasis pengolahan citra diantaranya :
1. Andrizal, Dodon Y, Aulia. R. Visual inspection berbasis web camera untuk menentukan pemutuan dan tingkat kematangan buah tomat. Hasil penelitian adalah dengan mendeteksi komposisi komponen warna buah tomat dapat digunakan untuk menentuan tingkat kematangan buah tomat. Klasifikasi ukuran dapat ditentukan dengan dengan menghitung jumlah pixel gelap dari objek setelah di konversi dari citra warna ke citra biner.

2. Tria A.W, Yudi $P$ dengan judul penelitian Implementasi visi komputer dan segmentasi citra untuk klasifikasi bobot telur ayan ras. Hasil penelitian adalah jumlah pixel gelap dari citra biner telur sebanding dengan ukuran telur tersebut.

3. Yusron Rijal, Riza Dhian Ariefianto," Deteksi Wajah Berbasis Segmentasi Model Warna Menggunakan Template Matching Pada Objek Bergerak", Seminar Nasional Aplikasi Teknologi Informasi, Yogyakarta, 2008. Hasil penelitian adalah proses segmentasi sangat bergantung pada kondisi pencahayaan. Akibatnya, nilai ambang pada suatu kondisi pencahayaan dengan kondisi pencahayaan yang lain bisa jadi berbeda.

Dengan melakukan pengolahan citra berupa konversi citra warna ke citra biner, maka setiap nilai citra warna dengan rentang nilai tertentu dapat diwakili oleh dua kombinasi nilai yaitu 0 untuk terang dan 255 untuk gelap. Hal ini dapat digunakan untuk menandai kondisi suatu permukaan objek seperti kemasan kaleng. Untuk kemasan kaleng warna silver terutama kemasan kaleng minuman, kondisi kaleng yang tidak cacat terlihat sepeti warna aslinya, sedangkan permukaan kemasan kaleng yang cacat berubah menjadi warna. Ketika dikonversi menjadi citra biner, kondisi tanpa cacat diwakili warna putih dan kondisi cacat diwakili warna gelap. Semakin mulus kemasan kaleng maka jumlah pixel gelap semakin kecil dan sebaliknya semakin cacat kaleng tersebut, 
maka jumlah pixel gelap semakin tinggi. Untuk menghasilkan keputusan dilakukan perbandingan jumlah pixel gelap kaleng sempurna dan jumlah pixel gelap kaleng yang diidentifikasi.

\section{METODOLOGI}

Visual inspection terhadap suatu objek dapat dilakukan dengan mengenali ciri-ciri dari objek yang diamati melalui panca indra misalnya melalui mata. Penggunaan web camera dapat digunakan sebagai pengganti fungsi mata untuk mengamati kondisi kemasan minuman kaleng. Hasil citra capture dari kamera diolah untuk mendapatkan ciri-ciri dari objek yang diamati. Adapun tahapan yang dilakukan pada penelitian ini adalah :

a. Capture image beberapa kemasan kaleng yang tidak cacat menggunakan webcamera dengan posisi dan jarak kamera yang tetap dengan latar belakang putih serta dengan pencahayaan yang tetap.

b. Konversi image dari citra warna ke citra hitam putih atau citra biner dan lakukan proses cropping.

c. Hitung jumlah pixel hitam setiap image yang telah diolah.

d. Hitung nilai rata-rata jumlah pixel hitam untuk semua image yang telah diolah. dan jadikan sebagai data referensi awal.

e. Lakukan proses yang sama dengan langkah a - d untuk kemasan kaleng yang cacat.

f. Proses identifikasi dilakukan dengan perbandingan jumlah pixel hitam antara image kemasan kaleng yang di capture dengan data referensi.

g. Lakukan perubahan-perubahan nilai data referensi untuk mendapatkan nilai rentang referensi agar hasil keputusan identifikasi sesuai dengan yang diinginkan.

h. Ketelitian tingkat identifikasi dilakukan terhadap identifikasi kaleng cacat, kaleng tidak cacat dan random (kaleng cacat dengan variasi kecacatan yang berbeda dan kaleng tidak cacat) .

\section{HASIL DAN PEMBAHASAN}

Sistem yang dibuat ini diimplementasikan pada sistem embedded dengan komponen utama berupa Mini Personal Computare (Mini PC) Raspberry PI dari Raspberry Foundation. Kamera WEB camera digunakan sebagai komponen capture image yang akan mengambil gambar dari bagian penutup permukaan kemasan minuman kaleng. Kamera dipasang secara statis dengan jarak $10 \mathrm{~cm}$ dari kamera. Ruang capture kamera dibuat tertutup dan dilengkapi dengan pencahayaan yang tetap. Gambar 3 merupakan blok diagram proses sistem. Proses dimulai dengan capture kemasan kaleng, citra hasil capture di konversi dari citra warna ke citra biner. Kemudian dihitung jumlah pixel gelap dari citra tersebut dan selanjutnya dibandingkan dengan data referensi untuk menghasilkan keputusan identifikasi.

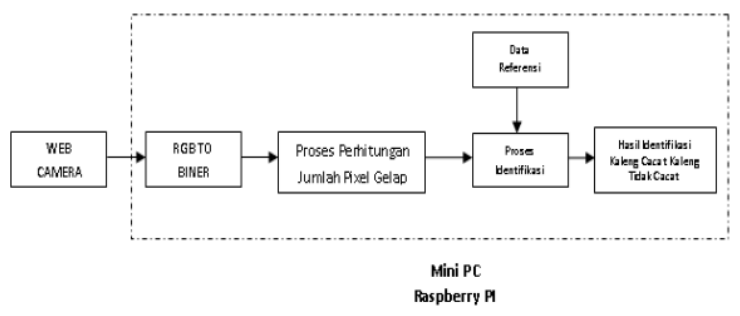

Gambar 4. Blok diagram proses sistem identifikasi

Tahapan proses penelitian :

A. Tahap persiapan

Pada tahap ini, disiapkan sistem yang digunakan pada ruang capture kamera tertutup dengan pencahayaan yang tetap.

B.Tahap pembuatan data referensi Data referensi yang

Data referensi merupakan data pembanding untuk pengambilan keputusan. Sebagai referensi data awal sebelum di tuning didapat dari hasil capture kemasan kaleng tidak cacad sebanyak 30 kali. Citra warna hasil capture diolah menjadi citra biner dan di crop sesuai dengan bentuk permukaan kemasaan kaleng. Selanjutnya dihitung jumlah pixel gelap untuk setiap image yang di capture, serta nilai rata-rata 
jumlah pixel gelap. Hasil data referensi awal diperlihatkan pada tabel 1 .

Tabel 1. Nilai pixel gelap dan nilai rata-rata pixel gelap data referensi awal.

\begin{tabular}{cc}
\hline No & Jumlah pixel gelap \\
\hline 1. & 10789 \\
2. & 11060 \\
3. & 9897 \\
4. & 10654 \\
5. & 8890 \\
6. & 11201 \\
7. & 10671 \\
8. & 10991 \\
9. & 11004 \\
10. & 11324 \\
11. & 9982 \\
12. & 8867 \\
13. & 9760 \\
14. & 10657 \\
15. & 8719 \\
16. & 10901 \\
17. & 11102 \\
18. & 12020 \\
19. & 11800 \\
20. & 10540 \\
21. & 10231 \\
22. & 8601 \\
23. & 8902 \\
24. & 10201 \\
25. & 11020 \\
26. & 9870 \\
27. & 10201 \\
28. & 10922 \\
29. & 10523 \\
30. & 9902 \\
Rata-rata & 10373 \\
& \\
\hline &
\end{tabular}
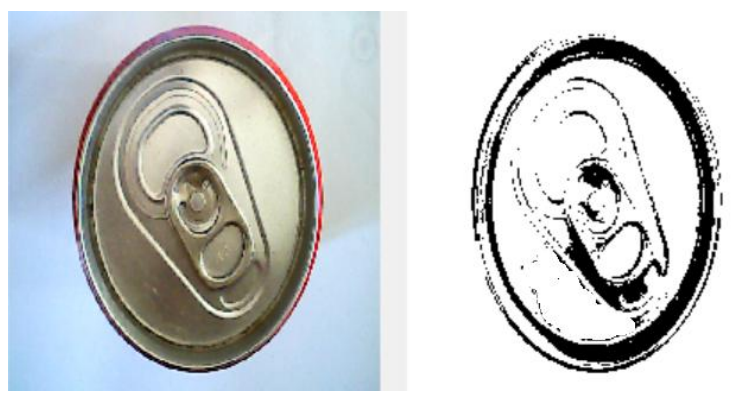

Gambar 5. Hasil capture, proses crop dan konversi RGB To Biner kemasan kaleng tidak cacat
C. Proses perhitungan pixel gelap kemasan kaleng cacat

Proses ini bertujuan untuk mengamati dan menghitung jumlah pixel gelap kemasan kaleng cacat. Kemasan kaleng cacat yang digunakan sebanyak 30 bentuk kerusakan yang berbeda-beda, dengan kerusakan hanya pada sisi bagian atas.
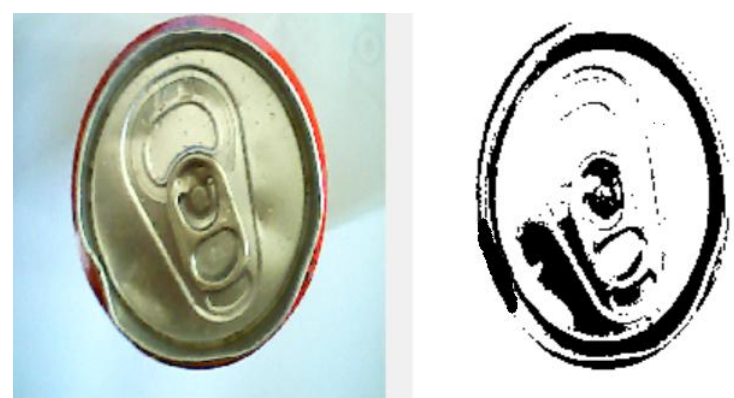

Gambar 6. Hasil capture, proses crop dan konversi RGB To Biner kemasan kaleng cacat Hasil perhitungan jumlah pixel genap diperlihatkan pada tabel 2 .

Tabel 2. Hasil perhitungan jumlah pixel gelap kemasan kaleng cacat.

\begin{tabular}{lc}
\hline No & Jumlah pixel gelap \\
\hline 1. & 12900 \\
2. & 15799 \\
3. & 18800 \\
4. & 21001 \\
5. & 26020 \\
6. & 10201 \\
7. & 21034 \\
8. & 17400 \\
9. & 13400 \\
10. & 11202 \\
11. & 11040 \\
12. & 16702 \\
13. & 19023 \\
14. & 10899 \\
15. & 9921 \\
16. & 12023 \\
17. & 28010 \\
18. & 20198 \\
19. & 15890 \\
20. & 13728 \\
21. & 17890 \\
22. & 11304 \\
23. & 12090
\end{tabular}




\begin{tabular}{cc}
\hline 24. & 25023 \\
25. & 17569 \\
26. & 26431 \\
27. & 10272 \\
28. & 19054 \\
29. & 12897 \\
30. & 23673 \\
Rata-rata & 16713
\end{tabular}

D. Tahap pengujian identifikasi

Tahap pengujian ini dilakukan untuk mendapatkan hasil keputusan identifikasi ketika sistem mendeteksi kemasan kaleng tidak cacat, cacat dan acak (cacat dan tidak cacat). Hal ini dilakukan dengan mengatur nilai referensi awal lebih kecil dari 10373. Selanjutnya dilakukan uji sebagai berikut :

\section{Uji identifikasi kemasan kaleng tidak cacat.}

Hasil identifikasi kemasan kaleng tidak cacat diperlihatkan pada tabel 3.

Tabel 3. Hasil identifikasi kemasan kaleng tidak cacat sebanyak 30 kali.

\begin{tabular}{|c|c|c|}
\hline No & $\begin{array}{c}\text { Jumlah pixel } \\
\text { gelap }\end{array}$ & $\begin{array}{c}\text { Hasil } \\
\text { Identifikasi }\end{array}$ \\
\hline 1. & 10510 & Tidak cacat \\
\hline 2. & 10400 & Tidak cacat \\
\hline 3. & 8230 & Tidak cacat \\
\hline 4. & 11200 & cacat \\
\hline 5. & 8976 & Tidak cacat \\
\hline 6. & 10437 & Tidak cacat \\
\hline 7. & 10021 & Tidak cacat \\
\hline 8. & 16890 & cacat \\
\hline 9. & 10301 & Tidak cacat \\
\hline 10. & 9721 & Tidak cacat \\
\hline 11. & 13211 & cacat \\
\hline 12. & 9987 & Tidak cacat \\
\hline 13. & 10021 & Tidak cacat \\
\hline 14. & 10400 & Tidak cacat \\
\hline 15. & 12340 & cacat \\
\hline 16. & 10711 & cacat \\
\hline 17. & 9980 & Tidak cacat \\
\hline 18. & 8921 & Tidak cacat \\
\hline 19. & 7801 & Tidak cacat \\
\hline 20. & 8234 & Tidak cacat \\
\hline 21. & 10122 & Tidak cacat \\
\hline 22. & 10555 & Tidak cacat \\
\hline 23. & 16700 & cacat \\
\hline
\end{tabular}

\begin{tabular}{lcc}
\hline 24. & 9780 & Tidak cacat \\
25. & 8872 & Tidak cacat \\
26. & 9821 & Tidak cacat \\
27. & 10899 & cacat \\
28. & 10123 & Tidak cacat \\
29. & 14520 & cacat \\
30. & 10400 & Tidak cacat
\end{tabular}

Dari 30 kali pengujian persentasi keberhasilan sistem dalam mengidentifikasi kemasan kaleng tidak cacat adalah : 22/30* $100 \%=73 \%$. Selanjutnya dilakukan perubahan nilai data referensi menjadi 11000. maka keberhasilan sistem menjadi $80 \%$.

Uji identifikasi kemasan kaleng cacat. Hasil identifikasi kemasan kaleng cacat diperlihatkan pada tabel 4. Referensi data yang digunakan adalah 11000 .

Tabel 4. Hasil identifikasi kemasan kaleng cacat sebanyak 30 kali.

\begin{tabular}{|c|c|c|}
\hline No & $\begin{array}{c}\text { Jumlah pixel } \\
\text { gelap }\end{array}$ & $\begin{array}{c}\text { Hasil } \\
\text { Identifikasi }\end{array}$ \\
\hline 1. & 14510 & cacat \\
\hline 2. & 16400 & cacat \\
\hline 3. & 18230 & cacat \\
\hline 4. & 21200 & cacat \\
\hline 5. & 10976 & Tidak cacat \\
\hline 6. & 15437 & cacat \\
\hline 7. & 19021 & cacat \\
\hline 8. & 16890 & cacat \\
\hline 9. & 12301 & cacat \\
\hline 10. & 14021 & cacat \\
\hline 11. & 13211 & cacat \\
\hline 12. & 19987 & cacat \\
\hline 13. & 22021 & cacat \\
\hline 14. & 10400 & Tidak cacat \\
\hline 15. & 12340 & cacat \\
\hline 16. & 18711 & cacat \\
\hline 17. & 19980 & cacat \\
\hline 18. & 18921 & cacat \\
\hline 19. & 27801 & cacat \\
\hline 20. & 28234 & cacat \\
\hline 21. & 10122 & Tidak cacat \\
\hline 22. & 19555 & cacat \\
\hline 23. & 16700 & cacat \\
\hline 24. & 9780 & Tidak cacat \\
\hline 25. & 28872 & cacat \\
\hline 26. & 19821 & cacat \\
\hline
\end{tabular}




$\begin{array}{lll}27 . & 12899 & \text { cacat } \\ 28 . & 15123 & \text { cacat } \\ 29 . & 14520 & \text { cacat } \\ 30 . & 24400 & \text { cacat }\end{array}$

Keberhasilan sistem mengidentifikasi kemasan kaleng cacat adalah 25/30*100\% $=83,33 \%$

\section{Uji ketelitian identifikasi sistem}

Uji ini dilakukan terhadap sejumlah kemasan kaleng minuman yang bervariasi dalam hal ini cacat dan tidak cacat secara acak.

Tabel 5 menunjukkan hasil identifikasi sistem yang dilakukan sebanyak 30 kali.

Tabel 5. Hasil identifikasi sistem mendeteksi kemasan kaleng secara acak.

\begin{tabular}{|c|c|c|c|}
\hline No & $\begin{array}{c}\text { Jumlah } \\
\text { pixel } \\
\text { gelap }\end{array}$ & $\begin{array}{c}\text { Hasil } \\
\text { Identifikasi }\end{array}$ & $\begin{array}{l}\text { Kondisi } \\
\text { kemasan }\end{array}$ \\
\hline 1. & 14516 & cacat & cacat \\
\hline 2. & 16408 & cacat & cacat \\
\hline 3. & 10930 & Tidak cacat & cacat \\
\hline 4. & 21200 & cacat & cacat \\
\hline 5. & 1098 & Tidak cacat & $\begin{array}{l}\text { Tdk } \\
\text { cacat }\end{array}$ \\
\hline 6. & 9843 & Tidak cacat & $\begin{array}{l}\text { Tdk } \\
\text { cacat }\end{array}$ \\
\hline 7. & 14021 & cacat & cacat \\
\hline 8. & 10070 & Tidak cacat & $\begin{array}{l}\text { Tdk } \\
\text { cacat }\end{array}$ \\
\hline 9. & 10801 & Tidak cacat & cacat \\
\hline 10. & 14021 & cacat & cacat \\
\hline 11. & 10211 & Tidak cacat & $\begin{array}{l}\text { Tdk } \\
\text { cacat }\end{array}$ \\
\hline 12. & 19900 & cacat & cacat \\
\hline 13. & 22321 & cacat & cacat \\
\hline 14. & 10460 & Tidak cacat & $\begin{array}{c}\text { Tdk } \\
\text { cacat }\end{array}$ \\
\hline 15. & 10340 & cacat & $\begin{array}{c}\text { Tdk } \\
\text { cacat }\end{array}$ \\
\hline 16. & 18711 & cacat & cacat \\
\hline 17. & 11080 & cacat & $\begin{array}{l}\text { Tdk } \\
\text { cacat }\end{array}$ \\
\hline 18. & 9821 & Tidak cacat & $\begin{array}{l}\text { Tdk } \\
\text { cacat }\end{array}$ \\
\hline 19. & 27791 & cacat & cacat \\
\hline 20. & 8234 & Tidak cacat & Tdk \\
\hline
\end{tabular}

\begin{tabular}{|c|c|c|c|}
\hline & & & cacat \\
\hline 21. & 10122 & Tidak cacat & cacat \\
\hline 22. & 17558 & cacat & cacat \\
\hline 23. & 11700 & cacat & $\begin{array}{l}\text { Tdk } \\
\text { cacat }\end{array}$ \\
\hline 24. & 9789 & Tidak cacat & Tdk cact \\
\hline 25. & 28978 & cacat & cacat \\
\hline 26. & 10821 & Tidak cacat & $\begin{array}{c}\text { Tdk } \\
\text { cacat }\end{array}$ \\
\hline 27. & 10819 & Tidak cacat & cacat \\
\hline 28. & 10623 & Tidak cacat & cacat \\
\hline 29. & 10520 & Tidak cacat & $\begin{array}{c}\text { Tdk } \\
\text { cacat }\end{array}$ \\
\hline 30. & 20409 & cacat & cacat \\
\hline
\end{tabular}

Berdasarkan hasil uji identifikasi pada tabel 5, didapatkan kemampuan sistem mengidentifikasi kondisi kemasan kaleng sesuai dengan kondisi yang sebenarnya adalah : $20 / 30 * 100 \%=66,67 \%$.

Hal ini disebabkan karena posisi peletakan kemasan kaleng selalu berubah sehingga hasil capture yang didapat juga berubah.

\section{SIMPULAN}

Berdasarkan hasil pengujian dan analisa, dapat diperoleh beberapa kesimpulan sebagai berikut :

1. Permukaan kaleng yang cacat akan menyebabkan perubahan warna, sehingga dapat teridentifikasi sebagai kecacatan yang ditandai dengan pixel gelap dari citra biner.

2. Untuk hasil identifikasi dengan menggunakan kaleng tidak cacat memiliki tingkat keberhasilan dengan persentase $80 \%$

3. Hasil identifikasi dengan menggunakan kaleng cacat memiliki tingkat keberhasilan dengan persentase 83,33\%.

4. Tingkat ketelitian sistem mengidentifikasi kemasan kaleng sesuai dengan kondisi yang sebenarnya (cacat atau tidak cacat) adalah $66,67 \%$.

\section{SARAN}

Berdasarkan hasil pengujian dan analisa yang telah dilakukan, dapat diperoleh beberapa saran untuk penelitian selanjutnya sebagai berikut : 
1. Penelitian ini masih terbatas untuk penutup kemasan kaleng dengan warna silver, selanjutnya dapat dikembangkan untuk warna yang lain.

2. Diharapkan untuk penelitian selanjutnya sistem dapat mengidentifikasi tidak hanya penutup kemasan saja akan tetapi juga sisi-sisi lainnya.

3. Pengembangan selanjutnya diharapkan sistem dapat bekerja secara on line yang terintegrasi dengan sistem sortir dan sehingga dapat dimanfaatkan untuk sistem visual inspection otomatis.

\section{UCAPAN TERIMA KASIH}

Terima kasih kepada Politeknik Negeri Padang yang telah mendanai kegiatan pengabdian kepada masyarakat melalui dana BOPTN, yang akhirnya menghasilkan jurnal ilmiah ini.

\section{DAFTAR PUSTAKA}

Andrizal, Dodon Y, Aulia R," Implementasi Web Camera Sebagai Visual Inspection Otomatis Untuk Proses Pemutuan Ukuran dan Tingkat Kematangan Buah Tomat ", Jurnal Ilmiah Elektron, Volume 4 No 2 Tahun 2012.

Adhi, Tria Wijaya dan Yudi Prayudi.,"Implementasi Visi

Komputer dan Segmentasi Citra untuk Klasifikasi Bobot Telur Ayam Ras",Jurnal seminar nasionalaplikasi teknologi informasi (SNATI), tahun 2010

Fauzi, M.H. dan H. Tjandrasa," Implementasi Thresholding Citra Menggunakan Algoritma Hybrid Optimal Estimation", Institut Teknologi Sepuluh Nopember. Surabaya, tahun 2010.

Iswahyudi, Catur. 2010. Prototype Aplikasi Untuk Mengukur Kematangan Buah
Apel Berdasar Kemiripan Warna. Jurnal Fakultas Teknologi Industri Institut Sains \& Teknologi AKPRIND Yogyakarta. Tidak diterbitkan

Rangkuti, Haris dan Marimin," Analisis Citra Buah-Buahan Dengan Algoritma Fagin dan Threshold", Jurnal nasional aplikasi teknologi (SNATI). tahun 2008.I

Rijal, Yusron dan Riza Dhian Ariefianto,"

Deteksi Wajah Berbasis Segmentasi Model Warna Menggunakan Template Matching Pada Objek Bergerak",Jurnal Seminar Nasional Aplikasi Teknologi Informasi 2008.

Sanjana P, P.Mahalakshmi, A.John C S,R.Swathi,"Smart Surveillance Monitoring System Using Raspberry PI and PIR Sensor",Sanjana Prasad et al, / (IJCSIT) International Journal of Computer Science and Information Technologies, Vol. 5 (6) , 2014.

Thiang, Leonardus I," Otomatisasi Pemisah Buah Tomat Berdasarkan Ukuran dan Warna Menggunakan Webcam Sebagai Sensor," Jurnal seminar nasional ilmu komputer dan aplikasinya (SNIKA), tahun 2008.

Utama, J., "Akuisisi Citra Digital Menggunakan Pemrograman Matlab", Majalah Ilmiah UNIKOM. Vol.9, Hal 75

Wijaya, T.A. dan Y. Prayudi. 2010. "Implementasi Visi Komputer dan Segmentasi Citra Untuk Klasifikasi Bobot Telur Ayam Ras”. Yogyakarta.

Wibisono, Setyawan, "Klasifikasi Tingkat Ketuaan Cabe Merah Besar, ".http://www.google.com/jurna 1/kalsifikasi-tingkat-ketuaan/pdf.

Diakses tanggal $1 \quad$ April 2016 
Y.K.Wang,CT.Fang, CY.Ke,"Real-time camera anomaly detection for realworld video surveillance", Machine Learning and Cybernetics (ICMLC), International Conference on IEEE, Volume: 4, 2011.

Yusron Rijal , Riza Dhian Ariefianto," Deteksi Wajah Berbasis Segmentasi Model Warna Menggunakan Template Matching Pada Objek Bergerak", Seminar Nasional Aplikasi Teknologi Informasi, Yogyakarta, 2008. 